\title{
From babirusa (Babyrousa babyrussa) to domestic pig: the nutrition of swine
}

\author{
BY KRISTIN LEUS ${ }^{1}$ AND ALASTAIR A. MACDONALD ${ }^{2}$ \\ ${ }^{1}$ Royal Zoological Society of Antwerp, Koningin Astridplein 26, 2018 Antwerp, Belgium \\ ${ }^{2}$ Department of Preclinical Veterinary Sciences, The University of Edinburgh, Summerhall, \\ Edinburgh $\mathrm{EH} 9 \mathrm{IQH}$
}

Interest in the nutrition of wild and captive wild animals has grown exponentially during the last few years. In the past, the amount of research carried out on domesticated animals, mainly geared towards improving economic efficiency of production of meat and dairy products, vastly outweighed research performed on wild animals. During the last two decades heightened public awareness of the need for nature conservation and for respect for animal welfare have brought new reasons for, and meaning to, further research in the fields of both domestic and wild animal nutrition.

As natural habitat becomes more and more fragmented and as wild animals are more and more confined to protected wildlife areas designated by man, a thorough knowledge of the feeding ecology of the wild animals living in these areas becomes essential for the successful conservation of these species. Furthermore, assisting nature conservation now constitutes one of the main goals of modern zoos (International Union of the Directors of Zoological Gardens \& Conservation Breeding Specialist Group, 1993). This is demonstrated by the many captive breeding programmes that are being coordinated by zoos in cooperation with field researchers (International Species Inventory System, 1996). It quickly became apparent that the 'trial and error method' of feeding wild animals in captivity, which had often been the case in the past, was no longer sufficient for these endangered animals (Dierenfeld, 1996). Since all but two of the fourteen species comprising the family of the Suidae are threatened to varying degrees (at species level or because they include threatened subspecies; Oliver, 1993, 1995; Table 1), and since at least eleven of the fourteen species are held in captivity in zoos around the world, the Suidae more than deserve the serious attention of animal nutritionists (Conklin \& Dierenfeld, 1994). Although the need for research into wild animal nutrition has been recognized for certain taxa (e.g. ruminants: Hofmann \& Matern, 1988; Hoffmann, 1989; Bodmer, 1990; Robbins et al. 1995; Conklin-Brittain \& Dierenfeld, 1996), for others such as wild pigs, views like 'pigs eat everything', 'all pigs root' and ' a pig is a pig' (i.e. all pigs are alike nutritionally) still prevail.

It was through studies into the diet and foraging behaviour of one of these endangered suids, the babirusa (Babyrousa babyrussa; Leus, 1994; Leus \& Morgan, 1995; Leus \& Vercammen, 1996), that the authors became aware of the sheer paucity of information on the nutrition of wild pigs other than the Eurasian wild pig (Sus scrofa), and the potential for important and interesting discoveries. With the present paper we wish to raise the interest of animal nutritionists in these enigmatic animals and to provide the interested researcher with a brief guide to the main literature and characteristics of the diets of wild pigs. 


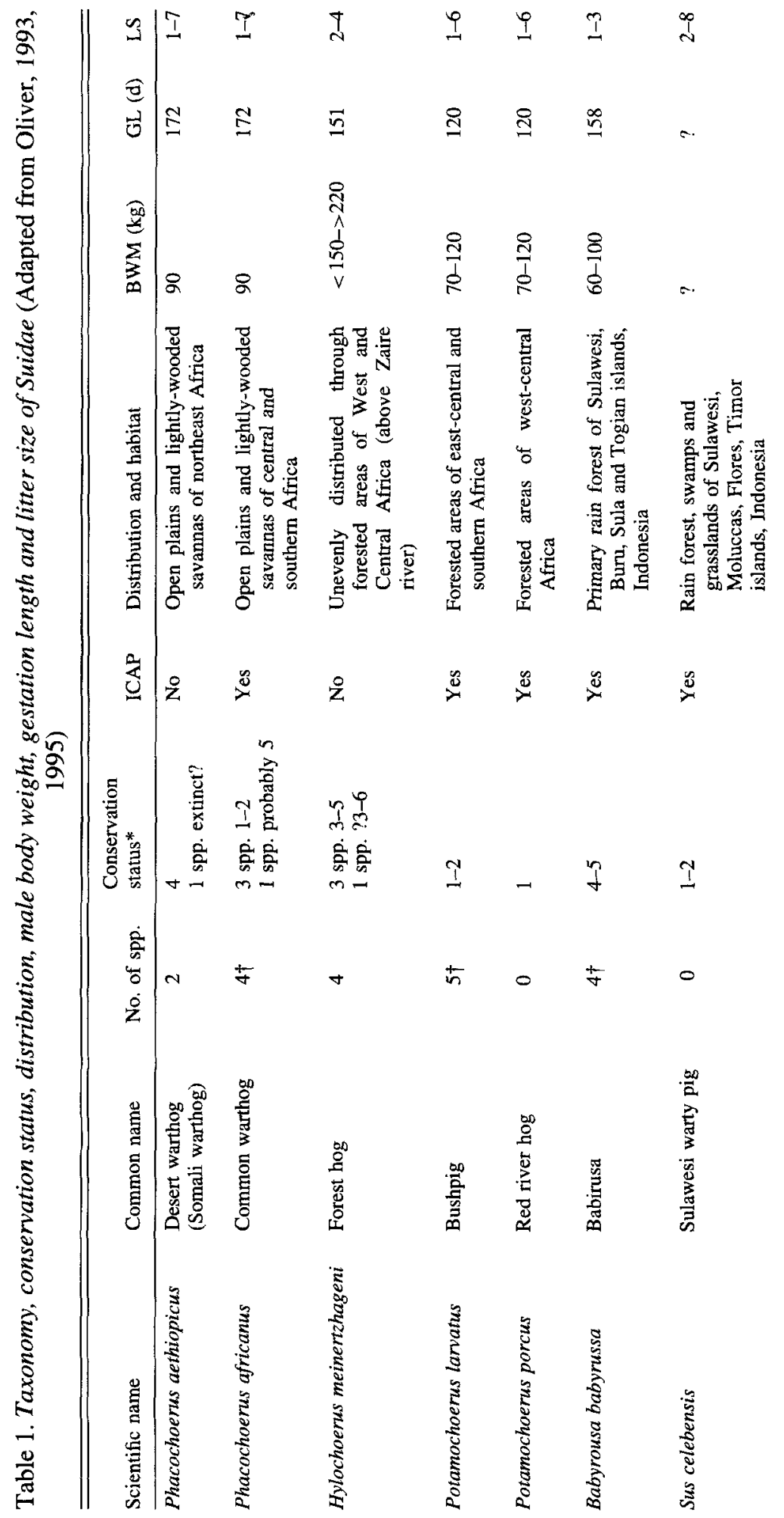




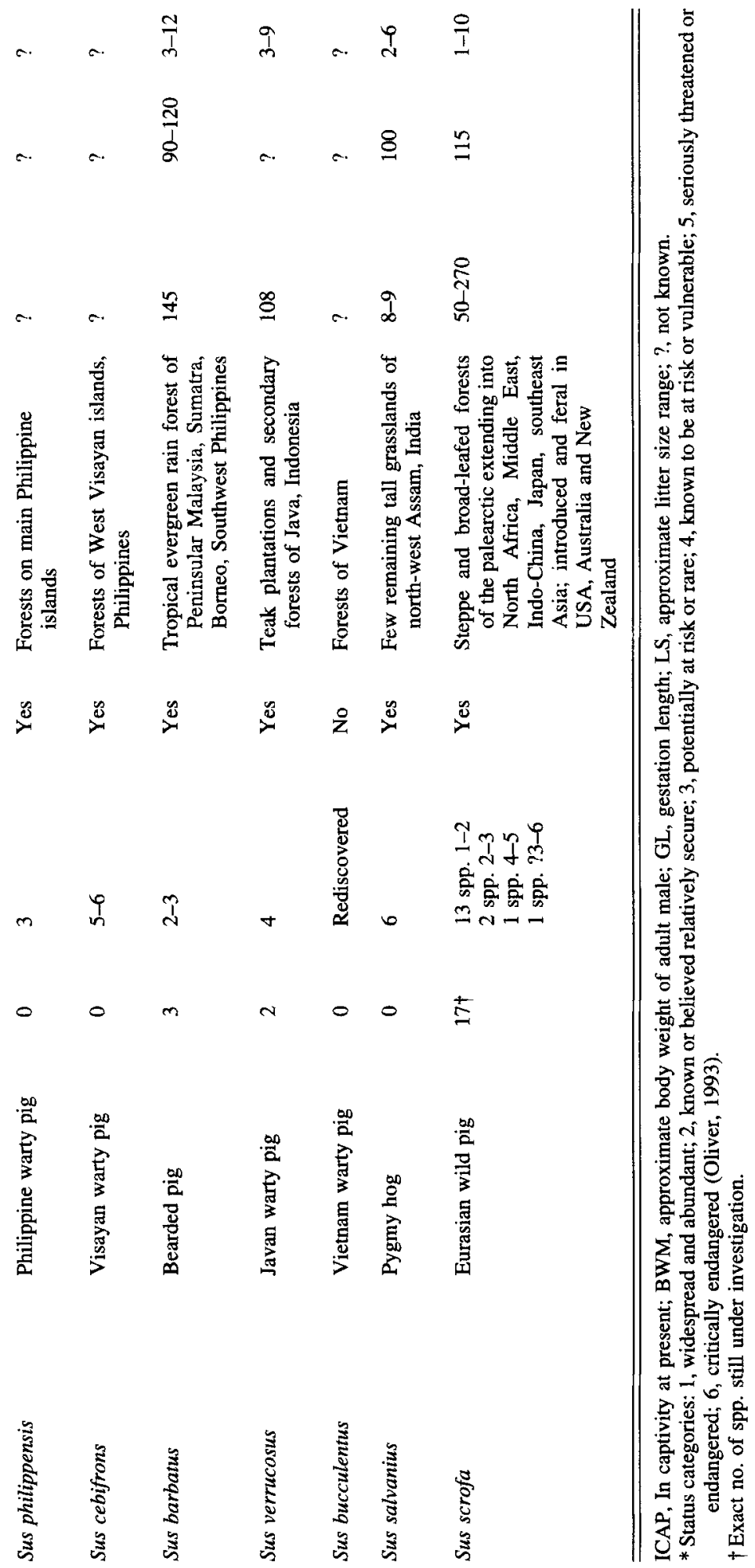




\section{WILD-PIG DIETS IN SITU}

\section{Habitat preference, climate, foraging behaviour and diet composition}

Although all pig species are truly omnivores, it is reasonable to expect significant differences in the proportions occupied by each of the diet constituents, when considering differences in habitat preferences (Table 1) and foraging methods.

Warthogs (Phacochoerus spp.) avoid densely wooded vegetation and are found only in open savanna habitats (Vercammen \& Mason, 1993). This is reflected in their diet. Warthogs are selective grazers (Frädrich, 1965; Field, 1970; Cumming, 1975; Rodgers, 1984). During the wet season, the warthog diet is almost entirely composed of the leaves of short grasses (for example, see Cumming, 1975; $>90 \%$ of diet) with only a handful of species making up the bulk of the diet. However, during the dry season, when the grass leaves lose much of their nutritive value, warthogs preferentially consume rhizomes of different grass species (for example, see Cumming, 1975; 50-85\% of diet). Only warthogs, with the aid of their tusks and strengthened rhinarium, can excavate sun-baked soil in search of succulent roots (Cumming, 1975).

The distribution of the forest hog (Hylochoerus meinertzhageni) is limited to forested areas of Africa because of its need for forest cover, a thick understorey cover, and permanent water sources in at least part of its home range. However, foraging activities preferentially occur in transitional habitat zones between forest and open savanna such as wooded savannas, gallery forests etc. (d'Huart, 1978, 1993). Results from the only extensive ecological study of forest hogs to date, carried out in the Virunga National Park, (Democratic Republic of Congo), showed that their diet was composed mainly of five different grass species, with the preference changing according to the time of year (d'Huart, 1978). The forest hogs selectively ate the aerial parts of these grasses, even during the dry seasons when warthogs in the same region switched from eating grass leaves to rhizomes. Forest hogs root less frequently than warthogs and can only do so in soil that is not too compact.

Snout anatomy and using the bridge rather than the tip of the snout to root suggest that bushpigs (Potamochoerus larvatus) and red river hogs (Potamochoerus porcus) are adapted to moist forest habitats (Cumming, 1975). Their distribution is indeed confined to forested regions with limited seasonality in terms of moisture stress (Vercammen et al. 1993). Only one field study seems to have been undertaken on the red river hog (Oduro, 1989), but rather more information is available for the bushpig (Skinner et al. 1976; Breytenbach \& Skinner, 1982; Jones, 1984; Melton et al. 1989; Seydack, 1990; Seydack \& Bigalke, 1992). Bushpigs have a preference for fruit and aerial herbaceous material whenever these are available; subterraneous plant material only becomes important during the drier seasons. During the hot dry seasons, when no fruit is available and the soil in open areas is too hard, bushpigs may be forced to feed almost entirely on shrub roots uprooted in woodlands after light showers of early rain have softened up the earth (Jones, 1984).

Partly because of the great spatio-temporal plasticity in its diet, the Eurasian wild pig is the most widely distributed suid and occupies a very wide range of habitats, from semideserts to grasslands, forests and agricultural areas (Oliver et al. 1993). Nevertheless, most of the published quantitative dietary information concerns Eurasian wild pigs in temperate habitats (for review, see Briedermann, 1990). During a good fruiting year, acorns and beech nuts may comprise up to $80 \%$ of the diet from October to February. When accessible, agricultural products such as potatoes and grains form a major part of the diet during late spring and summer. During bad mast years, agricultural products together with subterranean plant parts and herbal material become more important. When no fruits or agricultural products are available, grasses, herbs and roots make up the bulk of the diet. 
Roots are included more during the dry seasons, and herbs and grasses during the wet season.

Bearded pigs of Borneo (Sus barbatus barbatus) and Malaysia and Sumatra ( $S$. barbatus oi) inhabit Dipterocarpaceae-dominated rain forests and have fruit as their main dietary item (Caldecott, 1991; Caldecott et al. 1993). However, dipterocarp trees tend to fruit together at long but irregular intervals of 5-7 years (Leus, 1997). As a response to this, bearded pigs forage in variable group sizes and will sometimes aggregate and migrate long distances in search of mass fruit crops (Caldecott \& Caldecott, 1985).

The very limited anecdotal information available on the diet of the babirusa suggests that fruit is also the main dietary item for this species (Leus, 1994, 1997). Babirusa live in the tropical rain forests of Sulawesi and the Moluccas, Indonesia, which contain a very limited number of dipterocarps; their place is taken by a wide variety of tree species which do not fruit gregariously (Leus, 1997). This may partially explain the relatively small group sizes of the babirusa (maximum of eight individuals; Patry et al. 1995). Additionally, babirusa have been observed in captivity to stand freely on their hind legs to browse the leaves off trees (Macdonald \& Leus, 1995). Due to the lack of a well-developed rostral bone, the babirusa is also the suid the least able to root, and only able to do so in very loose soil or mud (Macdonald, 1993). These characteristics are likely to be of consequence for the diet composition of this species.

Quantitative dietary information is not available for any of the other wild pig species and, for many, even anecdotal information is scarce and hard to find. References to the limited information available can be found in the publications edited by Klös (1991) and Oliver (1993).

\section{Nutrient content}

Differences in data-gathering methods, food-item classifications, yearly climatic patterns etc. preclude numerical comparison of proportions of food types in the diets. Similarly, the scarcity of data on the actual nutrient content of wild-pig diets also limits numerical comparisons in this field. Nevertheless, those fragments of information that are known suggest that many interesting facts remain to be discovered.

For example, despite having the reputation of eating 'everything', wild pigs in fact appear to be quite selective feeders, choosing, within their own dietary habits, the nutritionally-best-quality diet from what is available. During the wet season, the contents of the cardiac part of the warthog stomach had a crude protein $(\mathrm{N} \times 6.25 ; \mathrm{CP})$ content of $111 \mathrm{~g} / \mathrm{kg}$ compared with $90 \mathrm{~g} / \mathrm{kg}$ for the zebra, a non-selective grazer occupying the same habitat. During the late dry season this dropped to $71 \mathrm{~g} / \mathrm{kg}$ for the warthog and $51 \mathrm{~g} / \mathrm{kg}$ for the zebra. Clipped grass leaf material during the late dry season contained $51 \mathrm{~g} \mathrm{CP} / \mathrm{kg}$ (Rodgers, 1984). These data indicate that by selecting particular grass species for their leaves or rhizomes, warthogs were able to 'compose' a diet higher in CP than were nonselective grazers. The ability of pigs to select a diet that best suits the nutritional requirements of their species, breed and physical condition is now being extensively researched and used in commercial pork production (for example, see Kyriazakis et al. 1993).

Having selected the best available diet, wild pigs are able to adapt their life-history tactics to that plane of nutrition. One of the most extensive ecological studies on the bushpig compared populations from the southern and eastern Cape Province, South Africa (Seydack, 1990; Seydack \& Bigalke, 1992). Although there was no significant difference in the DM fractions of the stomach contents $(\mathrm{g} / \mathrm{kg})$ for CP (137v. 147), crude fibre (CF; $204 v$. 
199), and diethyl ether extract (EE: $60 v$. 59) between the southern and eastern bushpig populations, southern Cape bushpigs had a higher proportion of aciddetergent lignin $(223 \mathrm{~g} / \mathrm{kg} v .170 \mathrm{~g} / \mathrm{kg})$ and soluble carbohydrates $(142 \mathrm{~g} / \mathrm{kg} v .103 \mathrm{~g} / \mathrm{kg})$ and a lower proportion of ash $(103 \mathrm{~g} / \mathrm{kg} v .158 \mathrm{~g} / \mathrm{kg})$ in their stomach contents DM. Southern Cape bushpigs also showed a significantly lower feed CP : faeces CP (but equal faecal bacterial $\mathrm{N}$ levels) compared with the eastern Cape bushpigs (Seydack \& Bigalke, 1992). This reflected the poor nutrient quality of the sandstone-derived southern Cape soil resulting in a stress-tolerant vegetation. The differences in nutrient availability were reflected in the life-history tactics of the two populations; the eastern bushpigs showed a higher reproductive investment (small, young females having frequent, large litters with low survival rate) and the southern bushpigs adopted a higher somatic investment (larger, older females having infrequent, small litters with high survival rate; Seydack \& Bigalke, 1992).

Borneo bearded pigs exhibit most mating behaviour around the time of late flowering and early fruiting of the dipterocarps. A certain nutritional status of the female ( 1.5 finger widths of subcutaneous fat at the shoulder) appears to be necessary for her to be fully responsive to mating stimuli (Caldecott et al. 1993). The bearded pigs appear to be able to make efficient use of fatty food sources and can deposit a hand-span of subcutaneous fat in a few weeks if plenty of fatty dipterocarp nuts are available. Piglets of fat mothers grow and mature fast, and reproduce themselves within 1 year (Caldecott \& Caldecott, 1985). When dipterocarp fruiting is successful, the small sedentary populations which had been surviving on 'background' food sources (roots, shoots, invertebrates) may grow into medium to large populations moving from fruit crop to fruit crop. On rare occasions, when a series of consecutive litters can be raised to sexual maturity due to consecutive years with successful dipterocarp crops combined with exceptional supplies of background foods (e.g. successful oak crops supporting the population for part of the year and ordinary fruit crops the remaining part) populations of Bornean pigs can reach incredible sizes of thousands to tens of thousands of animals migrating over long distances in search of food (Caldecott \& Caldecott, 1985; Caldecott et al. 1993). By way of contrast, the Philippine bearded pigs (Sus barbatus ahoenobarbus) living in dipterocarp-poor forests do not show population eruptions and mass migrations (Caldecott, 1991). Studies into the nutritional composition of the diet of these two subspecies and its relationship to reproductive investment and aggregation patterns are bound to generate very interesting data. Similarly, evidence indicates that physical condition, timing of reproduction and conception rate of the Eurasian wild pig are also linked to the availability of high-energy fruits and agricultural products (for example, see Baber \& Coblentz, 1987; Briedermann, 1990; Massei et al. 1996).

The intake of vitamins and minerals by suids other than the Eurasian wild pig has not been widely investigated. A number of wild pig species are known to ingest soil and water at salt licks. Forest hogs actively consume the soil of termite hills and more than $500 \mathrm{~g} / \mathrm{kg}$ faecal fresh weight can be composed of soil (d'Huart, 1978). The only pygmy hog (Sus salvanius) stomach investigated so far had a soil content of $500 \mathrm{~g} / \mathrm{kg}$ DM (Oliver, 1991). Babirusa and Sulawesi warty pigs (Sus celebensis) have been observed to drink the water, lick the stones and eat the soil of volcanic hot springs in Sulawesi (Patry et al. 1995). Warthogs are known to chew animal bones (Cumming, 1975). It is suspected that the roots of the woody plants of the genus Cochlospermum form an important source of Ca for warthog in Nigeria (Amubode, 1991). Although Seydack (1990) provided data on the mineral content of the bushpig diet, the biological meaning of most of the results remains to be investigated. 
Without exception, all wild pig species include animal matter (invertebrates, vertebrates, eggs, carrion etc.) in their diet. However, most dietary studies have concentrated on the vegetable component of the diet. The nutritional importance of the different animal fractions in the diets of the different wild pig species, therefore, remains largely a mystery.

\section{GASTROINTESTINAL ANATOMY AND DIGESTION}

The anatomy of the gastrointestinal tract of wild pigs is said to be very similar to that of the domestic pig and is, therefore, generally considered as 'known'. This conclusion may be premature when declared without thorough study of the functional gross anatomy and histology of the gastrointestinal tract of each species (only nine first-hand papers could be found describing the gastrointestinal anatomy of swine other than the Eurasian wild pig and babirusa, and six of these papers are pre-1920 brief general descriptions with little or no histological data (Macdonald, 1991). Langer (1988) carried out detailed gross anatomical work on the warthog and bushpig stomach but had access to only a few fetal or neonatal specimens in suboptimal condition.

The domestic-pig stomach is unilocular, glandular and provided with a small diverticulum at the extremity of the fundus ventriculi. Few volatile fatty acids are produced in the stomach where acid- and enzyme-based digestion prevails. The intestinal tract includes a well-developed caecum and spiral colon with taenia and haustra which help to retain digesta long enough to allow extensive bacterial fermentation of almost all dietary cellulose and much of the hemicellulose to take place (Keys \& DeBarthe, 1974). Studies investigating possible differences from this general principle, based on the specified dietary habits of the individual wild pig species are very rare (for example, see Seydack, 1990).

The babirusa appears to be intriguingly different from the 'typical general principle'. Although its intestinal tract seems to be similar to that of other pigs (Mitchell, 1905, 1916), its stomach has a curious shape. Early anatomists believed that it formed a transition between the simple stomach of the Eurasian wild pig and the composite stomach of ruminants (Vrolik, 1843; Mayer, 1847; Davis, 1940). More recent investigations clearly indicated that, although this was not the case, there were significant differences between the stomach of the babirusa and those of other Suidae (Langer, 1988; Leus, 1994): there is a large fundus and diverticulum ventriculi, a large area covered by mucus-producing cardiac glands $(>70 \%$ of the internal stomach surface area compared with approximately $30 \%$ in the Eurasian wild pig) and the true gastric glands are confined to a small gastric unit (8-17\% of the total internal stomach surface area compared with approximately $30 \%$ in the Eurasian wild pig) at the distal end of the corpus ventriculi. The $\mathrm{pH}$ in the cardiac gland area ranged from 6.4 to 5.3 in the one animal where it was measured (Leus, 1994), which is a $\mathrm{pH}$ suitable for the long-term survival of micro-organisms (Bauchop, 1978). Preliminary observations on two other babirusa stomachs confirmed the presence of numerous Grampositive bacteria in the adherent and luminal mucus of the cardiac gland area (Leus, 1994).

In contrast to other forestomach fermenters, the babirusa stomach is clearly unilocular and does not show narrow constrictions between different stomach parts. Nevertheless, the sheer size of the cardiac gland area may be sufficiently large such that the normal passage of food through this mucous and micro-organism-rich environment is slow enough to allow some microbial fermentation to take place before the gastric gland area is reached. The presence of only a single marker excretion peak, together with a low metabolic faecal $\mathrm{N}$ loss $(1.3 \% v .4 .1 \%$ in the Eurasian wild pig) in babirusa fed on a zoo diet, suggested that no part of the digestive tract selectively held digesta longer than any other part and that 
caeco-colic fermentation may be less important in the babirusa than in the Eurasian wild pig (Conklin \& Dierenfeld, 1994).

If forestomach fermentation is more important for the babirusa than caeco-colic fermentation, and if the digesta retention time in the stomach is too short to allow extensive fermentation of cellulose, then we might expect that babirusa would show a higher digestibility of neutral-detergent fibre (NDF) and a lower digestibility of acid-detergent fibre (ADF) than the Eurasian wild pig. In each of the two studies investigating the digestive abilities of the babirusa, the animals did not voluntarily consume the total amount of hay or dried grass offered, which may in itself indicate an unsuitability of these fibre sources to the digestive system of the babirusa (Conklin \& Dierenfeld, 1994; Leus, 1994). Results of a comparative study feeding babirusa and domestic pigs (F1 hybrid Large White $\times$ Landrace pigs; LW) a barley-soyabean basal diet with $150-200 \mathrm{~g}$ dried grass added as a source of fibre, indicated that babirusa were better able to digest the NDF of the total diet (basal + grass) $(51.1 \%)$ than were the LW $(46.6 \%)$, but the digestibility of NDF from the dried grass alone did not differ between the two pig species. There were no differences between the two species in the efficiency of ADF digestion in the total diet, but the babirusa were less-efficient digesters of the ADF originating from dried grass alone (66.1\% v. 96.2\% for babirusa and LW respectively; Leus, 1994). The NDF and ADF digestibilities for babirusa fed on a zoo diet were 56.2 and $52.0 \%$ respectively (Conklin \& Dierenfeld, 1994), but direct comparison of values obtained by the two studies is complicated by the differences in the composition of the diets fed. The results obtained for the babirusa fit well within the general characteristics of the non-ruminant forestomach fermenters which are known to be specialized in the fermentation of the more-easilydigestible plant components (Hoffmann, 1989; Bodmer, 1990).

\section{WILD-PIG DIETS IN CAPTIVITY}

For a number of wild pig species, breeding and reproductive success in the wild was demonstrated to be dependent on the nutritional composition of the diet. The interaction between the plane of nutrition and reproduction in the domestic pig is also an extensive field of study (Cosgrove et al. 1995). A more thorough understanding of the nutritional details of the wild pig species in our zoos is, therefore, essential to the success of their conservation breeding programmes. This was nicely illustrated with a non-threatened wild pig species at San Diego Zoo: an overweight female red river hog only reproduced after her high-fat, high-sugar diet was changed to a high-fibre diet (Diamant, 1997). Despite the obvious necessity to monitor the diets fed to captive pigs, only a single study (of the babirusa) appears to have investigated diets currently fed to a wild pig species (Leus, 1994; Leus \& Morgan, 1995).

Diets offered to babirusa in nineteen zoos worldwide were analysed for their nutritional content, making use of published tables of food item compositions (Leus, 1994; Leus \& Morgan, 1995). The results indicated that a wide range of food items and nutrient amounts is being offered to babirusa daily: between 1400 and $4770 \mathrm{~g}$ total wet matter (excluding browse), 700 and $3770 \mathrm{~g}$ fruit and vegetables, 200 and $2260 \mathrm{~g}$ pellets, grains, bread, nuts and oils, 0 and $680 \mathrm{~g}$ meat, fish and eggs. This contained between 356 and $2108 \mathrm{~g} \mathrm{DM}, 43$ and $399 \mathrm{~g} \mathrm{CP}, 11$ and $151 \mathrm{~g}$ fat, 20 and $517 \mathrm{~g}$ Englyst fibre (Englyst $e t$ al. 1982 ) and 6 and $69 \mathrm{MJ}$ digestible energy (DE). Unpublished results of Leus and Macdonald suggest that an equally-wide range of values would be found if similar studies were to be carried out on other wild-pig species in zoos. The range of nutrients offered to these pigs is too wide for all these diets to answer to their nutritional requirements. Casual observations 
suggest a prevalence of obese pigs in zoological gardens, which in some cases has been known to cause reproductive (Diamant, 1997) or locomotive (K. Leus, unpublished results) problems. Moreover, in order to obtain a more accurate picture, the amounts of food consumed, rather than offered, need to be measured. Sadly, most zoos do not yet record this information routinely.

Data on the nutrient requirements of pigs in the wild upon which captive diets could be based are rare. Seydack (1990) estimated, from measurements of BMR, mean nutrient composition of the diet, and digestibility and energy content of the nutrients, that a $70 \mathrm{~kg}$ bushpig would need a daily ration of $1550 \mathrm{~g}$ DM of the mean bushpig diet in the Cape region $(250 \mathrm{~g} \mathrm{DM} / \mathrm{kg}, 11.7 \mathrm{~kJ} / \mathrm{g} \mathrm{DM}$, and as g/kg DM: CP 141, CF 202, EE 60, ash 160, Nfree extract 472). Adult wild boar (90-100 kg body weight) consumed a mean of $1975 \mathrm{~g}$ DM in successful mast years and $1425 \mathrm{~g} \mathrm{DM}$ in unsuccessful years (Briedermann, 1990). In the study of Conklin \& Dierenfeld (1994), the babirusa consumed all the offered primate biscuit, fruit and vegetables but only $45 \%$ of the pig and sow pellet and $10 \%$ of the hay. This resulted in a daily DM intake of $21 \mathrm{~g} / \mathrm{kg}$ body mass, which in the case of a $90 \mathrm{~kg}$ male would mean a daily DM intake of $1890 \mathrm{~g}$.

Leus (1994) and Leus \& Morgan (1995) estimated the daily CP requirement of a $90 \mathrm{~kg}$ male babirusa to be $82 \mathrm{~g}$ when assuming a babirusa body-protein weight of $120 \mathrm{~g} / \mathrm{kg}$ body weight, a protein score of 0.7 , a protein digestibility of 0.75 . CP requirements calculated for a $90 \mathrm{~kg}$ domestic Large White pig were $110 \mathrm{~g}$. From the daily DM requirement and the composition of the diet of the Cape bushpig (Seydack, 1990) we calculated that a $70 \mathrm{~kg}$ bushpig requires $219 \mathrm{~g} \mathrm{CP} / \mathrm{d}$. This appears high when compared with the calculated daily CP requirements for the babirusa. The difference may be partly explained by the relatively high CF content, and especially lignin, of the diet eaten by these bushpigs (Seydack, 1990; Seydack \& Bigalke, 1992); the latter may be expected to have a negative influence on the digestibility of other diet nutrients including CP (Sandoval et al. 1987). The apparent digestibility of $\mathrm{CP}$ for bushpigs in the Cape region was only $61.8 \%$, whereas it was assumed to be $70 \%$ in the babirusa calculations. Bushpigs in the Cape region, therefore, may have to eat more of a less-digestible diet. Wild boar showed a daily CP consumption of $235 \mathrm{~g}$ in good mast years and $153 \mathrm{~g}$ in bad mast years (Briedermann, 1990). The stomach contents of warthogs contained between 111 and $71 \mathrm{~g} \mathrm{CP} / \mathrm{kg}$ but the total daily intake remains as yet unknown (Rodgers, 1984).

The estimated daily DE requirements of a $90 \mathrm{~kg}$ male babirusa and Large White were calculated to be 11.0 and $13.5 \mathrm{MJ}$ respectively (Leus \& Morgan, 1995). Based on measurements for BMR, a $70 \mathrm{~kg}$ bushpig would need 18.2 MJ DE (Seydack, 1990). During good mast years wild boar daily consume $30.9 \mathrm{MJ} \mathrm{DE}$; during bad mast years this drops to 18.9 MJ (Briedermann, 1990).

Good quantitative information on the diet of wild pigs in the wild is needed to assess the adequacy of the diets currently being fed in captivity, and to make recommendations for changes.

\section{CONCLUSION}

In order to effectively manage, and where necessary conserve, wild-pig populations in the wild and in captivity, quantitative data must urgently be gathered on the composition of wild and captive diets, the nutritional composition of wild and captive dietary components, and on the digestive anatomy and physiology. Coordinated collection of such data would enable quantitative comparison between different wild pig species. 
The financial support for the babirusa studies from the Commission of the European Community, the Development Trust of the University of Edinburgh and the Balloch Trust is gratefully acknowledged. Thank you also to Colin and Maureen Warwick for their help with slides for the presentation, and to Mr Paul Vercammen and Dr Ellen Dierenfeld for helpful comments on the manuscript.

\section{REFERENCES}

Amubode, F. O. (1991). Spatial distribution and nutritive value of two species of Cochlospermum for warthog (Phacochoerus aethiopicus Pallas) in Kainji Lake Park, Nigeria. African Journal of Ecology 29, 295-301.

Baber, D. W. \& Coblentz, B. E. (1987). Diet, nutrition, and conception in feral pigs on Santa Catalina Island. Journal of Wildlife Management 51, 306-317.

Bauchop, T. (1978). Digestion of leaves in vertebrate arboreal folivores. In The Ecology of Arboreal Folivores, pp. 193-204 [G. Montgomery, editor]. Washington, DC: Smithsonian Institution Press.

Bodmer, R. E. (1990). Ungulate frugivores and the browser-grazer continuum. Oikos 57, 319-325.

Breytenbach, G. J. \& Skinner, J. D. (1982). Diet, feeding and habitat utilization by bushpigs Potamochoerus porcus Linnaeus. South African Journal of Wildlife Research 12, 1-7.

Briedermann, L. (1990). Schwarzwild (Wild Boar), 2nd ed. Berlin: VEB Deutscher Landwirtschaftsverlag.

Caldecott, J. (1991). Eruptions and migrations of bearded pig populations. Bongo 18, 233-243.

Caldecott, J. \& Caldecott, S. (1985). A horde of pork. New Scientist 107, 32-35.

Caldecott, J. O., Blouch, R. A. \& Macdonald, A. A. (1993). The bearded pig (Sus barbatus). In IUCN Status Survey and Conservation Action Plan for Pigs, Peccaries and Hippos, pp. 136-145 [W. L. R. Oliver, editor]. Gland: IUCN.

Conklin, N. L. \& Dierenfeld, E. S. (1994). Digestibility and passage of a zoo diet fed to babirusa (Babyrousa babyrussa). Der Zoologische Garten N.F. 64, 357-365.

Conklin-Brittain, N. L. \& Dierenfeld, E. S. (1996). Small ruminants: digestive capacity differences among four species weighing less than 20kg. Zoo Biology 15, 481-490.

Cosgrove, J. R., Charlton, S. T., Cosgrove, S. J., Zak, J. K. \& Foxcroft, G. R. (1995). Interactions between nutrition and reproduction in the pig. Reproduction in Domestic Animals 30, 193-200.

Cumming, D. H. M. (1975). A field study of the ecology and behaviour of warthog. Museum Memoir no. 7. Harare, Zimbabwe: The Trustees of the National Museums and Monuments of Rhodesia.

Davis, D. D. (1940). Notes on the anatomy of the babirusa. Field Museum of Natural History, Chicago (Zoological Series) 22, 363-911.

d'Huart, J. P. (1978). Écologie de l'Hylochère (Hylochoerus meinertzhageni Thomas) au Parc National des Virunga (Ecology of the Forest Hog (Hylochoerus meinertzhageni Thomas) in the Virunga National Park). Fondations pour favoriser les recherches scientifiques en Afrique, Series 2e, vol. 25. Brussels: Fonditions pour favoriser les recherches scientifiques en Afrique.

d'Huart, J. P. (1993). The forest hog (Hylochoerus meinertzhageni). In IUCN Status Survey and Conservation Action Plan for Pigs, Peccaries and Hippos, pp. 84-93 [W. L. R. Oliver, editor]. Gland, Switzerland: IUCN.

Diamant, K. (1997). Diet for a healthy zoo. Zoonooz March issue, 14-19.

Dierenfeld, E. S. (1996). Nutritional wisdom: adding the science to the art. Zoo Biology 15, 447-448.

Englyst, H. M., Wiggins, H. S. \& Cummings, J. H. (1982). Determination of the non-starch polysaccharides in plant foods by gas-liquid chromatography of constituent sugars as alditol acetates. Analyst 107, 307-318.

Field, C. R. (1970). Observations on the food habits of tame warthog and antelope in Uganda. East African Wildlife Journal 8, 1-17.

Frädrich, H. (1965). Zur Biologie und Ethologie des Warzenschweines (Phacochoerus aethiopicus Pallas), unter Berücksichtigung des Verhaltens anderer Suiden (On the biology and ethology of the warthog (Phacochoerus aethiopicus Pallas), taking into account the behaviour of other Suidae). Zeitschrift für Tierpsychologie 22, 328-393.

Hofmann, R. R. (1989). Evolutionary steps of ecophysiological adaptation and diversification of ruminants: a comparative view of their digestive system. Oecologia 78, 443-457.

Hofmann, R. R. \& Matern, B. (1988). Changes in gastrointestinal morphology related to nutrition in giraffes Giraffa camelopardalis: a comparison of wild and zoo specimens. International Zoo Yearbook 27, 168-176. International Species Inventory System (1996). Studbook Library CD-ROM, 1st ed. Apple Valley: ISIS.

International Union of the Directors of Zoological Gardens \& Conservation Breeding Specialist Group (1993). The World Zoo Conservation Strategy; The Role of Zoos and Aquaria of the World in Global Conservation, 1 st ed. Brookfield, IL: Chicago Zoological Society.

Jones, M. A. (1984). Seasonal changes in the diet of bushpig, Potamochoerus porcus Linn. in the Matopos National Park. South African Journal of Wildlife Research 14, 97-100.

Keys, J. E. \& DeBarthe, J. V. (1974). Cellulose and hemicellulose digestibility in the stomach, small intestine and large intestine of swine. Journal of Animal Science 39, 53-56. 
Klös, H.-G. (editor) (1991). Berichte der Internationalen Tagung über Wildschweine und Pekaris im Zoo Berlin 12-15 Juli 1990 (Proceedings of the International Meeting on Wild Pigs and Peccaries at Berlin Zoo 12-15 July 1990). Bongo 18, 1-300.

Kyrazakis, I., Leus, K., Emmans, G. C., Haley, C. S. \& Oldham, J. D. (1993). The effect of breed (Large White $\times$ Landrace $v$. purebred Meishan) on the diets selected by pigs given a choice between two foods that differ in their crude protein contents. Animal Production 56, 121-128.

Langer, P. (1988). The Mammalian Herbivore Stomach - Comparative Anatomy, Function and Evolution, 1 st ed. Stuttgart and New York: Gustav Fischer.

Leus, K. (1994). Foraging behaviour, food selection and diet digestion of Babyrousa babyrussa (Suidae, Mammalia). PhD Thesis, The University of Edinburgh.

Leus, K. (1997). The habitat and diet of the Sulawesi babirusa (Babyrousa babyrussa celebensis). In Population and Habitat Viability Assessment for the Babirusa (Babyrousa babyrussa), pp. 121-143 [J. Manansang, A. A. Macdonald, D. Siswomartono, P. Miller and U. Seal, editors]. Apple Valley: IUCN/SSC Conservation Breeding Specialist Group.

Leus, K. \& Morgan, C. A. (1995). Analyses of diets fed to babirusa (Babyrousa babyrussa) in captivity with respect to their nutritional requirements. IBEX Journal of Mountain Ecology 3, 41-44.

Leus, K, \& Vercammen, P. (1996). Behaviour of a male and female babinusa (Babyrousa babyrussa, Suidae, Mammalia) during the first few days after their move to a semi-natural enclosure. Der Zoologische Garten N.F. 66, 133-155.

Macdonald, A. A. (1991). Comparative study of the functional soft tissue anatomy in pigs and peccaries. Bongo 18, 273-282.

Macdonald, A. A. (1993). The Babirusa (Babyrousa babyrussa). In IUCN Status Survey and Conservation Action Plan for Pigs, Peccaries and Hippos, pp. 161-170 [W. L. R. Oliver, editor]. Gland: IUCN.

Macdonald, A. A. \& Leus, K. (1995). Creating a public understanding of the biology of the babirusa (Babyrousa babyrussa) within a caring zoo environment. IBEX Journal of Mountain Ecology 3, 37-40.

Massei, G., Genov, P. V. \& Staines, B. W. (1996). Diet, food availability and reproduction of wild boar in a Mediterranean coastal area. Acta Theriologica 41, 307-320.

Mayer, C. (1847). Beiträge zur Anatomie des Elephanten und der übrigen Pachydermen (Contributions to the anatomy of elephants and other Pachyderms). Novovum Actorum Academiae Casesareae LeopoldinoCatolinae Naturae Curiosum 22, 1-88.

Melton, D. A., Cooper, S. M. \& Whittington, A. E. (1989). The diet of bushpigs in a sugar-cane agroecosystem. South African Journal of Wildlife Research 19, 48-51.

Mitchell, P. C. (1905). On the intestinal tract of mammals. Transactions of the Zoological Society of London 17, 437-536.

Mitchell, P. C. (1916). Further observations on the intestinal tract of mammals. Proceedings of the General Meetings for Scientific Business of the Zoological Society of London, pp. 183-251. London: Zoological Society of London.

Oduro, W. (1989). Ecology of the red river hog in southern Nigeria. PhD Thesis, The University of Ibadan, Nigeria.

Oliver, W. L. R. (1991). Monographie des Zwergschweines (Sus salvanius) (Monograph on the pigmy hog (Sus salvanius)). Bongo 18, 21-38.

Oliver, W. L. R. (editor) (1993). IUCN Status Survey and Conservation Action Plan for Pigs, Peccaries and Hippos, 1st ed. Gland, Switzerland: IUCN.

Oliver, W. L. R. (1995). Taxonomy and conservation status of the Suiformes - an overview. IBEX Journal of Mountain Ecology 3, 3-5.

Oliver, W. L. R., Brisbin, L. \& Takahashi, S. (1993). The Eurasian wild pig (Sus scrofa). In IUCN Status Survey and Conservation Action Plan for Pigs, Peccaries and Hippos, pp. 112-121 [W. L. R. Oliver, editor]. Gland: IUCN.

Patry, M., Leus, K. \& Macdonald, A. A. (1995). Group structure and behaviour of babirusa (Babyrousa babyrussa) in Northern Sulawesi. Australian Journal of Zoology 43, 643-655.

Robbins, C. T., Spalinger, D. E. \& van Hoven, W. (1995). Adaptations of ruminants to browse and grass diets: are anatomical-based browser-grazer interpretations valid? Oecologia 103, $208-213$.

Rodgers, W. A. (1984). Warthog ecology in south east Tanzania. Mammalia 48, 327-350.

Sandoval, R. A., Nielsen, T. K. \& Sorensen, P. H. (1987). Effects of fibre on nutrient digestion and time of passage in growing pigs. Acta Agriculturae Scandinavica 37, 367-373.

Seydack, A. H. W. (1990). Ecology of the bushpig Potamochoerus porcus Linn. 1758 in the Cape Province, South Africa. PhD Thesis, University of Stellenbosch, Republic of South Africa.

Seydack, A. H. W. \& Bigalke, R. C. (1992). Nutritional ecology and life history tactics in the bushpig (Potamochoerus porcus): development of an interactive model. Oecologia 90, 102-112.

Skinner, J. D., Breytenbach, G. J. \& Maberly, C. T. A. (1976). Observations on the ecology and biology of the bushpig Potamochoerus porcus Linn. in the Northern Transvaal. South African Journal of Wildlife Research 6, 123-128. 
Vercammen, P. \& Mason, D. R. (1993). The warthogs (Phacochoerus africanus and P. aethiopicus). In IUCN Status Survey and Conservation Action Plan for Pigs, Peccaries and Hippos, pp. 75-84 [W. L. R. Oliver, editor]. Gland: IUCN.

Vercammen, P., Seydack, A. H. W. \& Oliver, W. L. R. (1993). The bush pigs (Potamochoerus porcus \& $P$. larvatus). In IUCN Status Survey and Conservation Action Plan for Pigs, Peccaries and Hippos, pp. 93-101 [W. L. R. Oliver, editor]. Gland: IUCN.

Vrolik, W. (1843). Recherches d'anatomie comparée sur le Babyrussa (Comparative anatomy of babirusa). Nieuwe Verhandelingen der Eerste Klasse van het Koninklijk-Nederlandsch Instituut van Wetenschappen, Letterkunde en Schoone Kunsten te Amsterdam 10, 207-248. 